\title{
РАЗВИТИЕ ГРАФОМОТОРНЫХ УМЕНИЙ И НАВЫКОВ У СТАРШИХ СЛАБОВИДЯЩИХ ДОШКОЛЬНИКОВ
}

\section{DEVELOPMENT OF GRAPHOMOTOR SKILLS AND ABILITIES IN SENIOR VISUALLY IMPAIRED PRESCHOOLERS \\ L. Myasnikova}

Summary: The article is devoted to the problem of preparing senior preschoolers with visual impairments for schooling. The idea of the need for special correctional work to prepare children's hands for writing is substantiated. The author identifies and describes the characteristic difficulties in the formation of graphomotor skills and abilities in children of the studied category, analyzes the reasons for these difficulties. Considerable attention is paid to the description of experimental work to overcome difficulties in mastering graphomotor skills and abilities in visually impaired senior preschool children.

Keywords: senior visually impaired preschoolers, graphomotor skills and abilities, visual perception, fine motor skills, hand-eye coordination, orientation in microspace, special correctional work.

\author{
Мясникова Людмила Владимировна \\ к.п.н., дочент, ФГБОУ ВО «Саратовский национальный \\ исследовательский государственный \\ университет им. Н.Г. Чернышевского» \\ myasnikovalv@gmail.com
}

Аннотация: Статья посвящена проблеме подготовки к обучению в школе старших дошкольников с нарушениями зрения. Обосновывается идея о необходимости проведения специальной коррекционной работы по подготовке рук детей к письму. Автор выделяет и описывает характерные трудности формирования графомоторных умений и навыков у детей исследуемой категории, анализирует причины этих трудностей. Значительное внимание уделяется описанию экспериментальной работы по преодолению трудностей в овладении графомоторных умений и навыков у слабовидящих детей старшего дошкольного возраста.

Ключевые слова: старшие слабовидящие дошкольники, графомоторные умения и навыки, зрительное восприятие, мелкая моторика, зрительномоторная координация, ориентировка в микропространстве, специальная коррекционная работа.
3 адача формирования графомоторных умений и навыков у дошкольников с нарушениями зрения является одной из важнейших в тифлопедагогике. От того, насколько легко и быстро ребёнок освоит новую для себя учебную деятельность зависит его дальнейшая успешность и, соответственно, комфортность пребывания в образовательном учреждении. К началу школьного обучения ребёнок должен овладеть многими умениями и навыками, которые облегчат процесс его обучения. Одной из главных задач подготовки дошкольника к обучению в школе является необходимость подготовить руку к письму, сформировать необходимые графомоторные навыки.

Для выработки навыка письма необходимо взаимодействие многих компонентов, поскольку процесс формирования графомоторных навыков и умений письма очень многогранный и охватывает множество различных сфер умственной деятельности ребенка, связан с работой всех участков коры головного мозга, хотя их роль в различных видах письма различна. Процесс овладения письмом может задерживаться из-за недостаточной морфологической и функциональной развитости отдельных участков коры головного мозга, в частности, лобных долей (6).

Графический навык в педагогической литературе определяется как автоматизированный способ дифференцировки и перекодирования звуков (фонем) речи в соответствующие буквы, начертание их на бумаге и вместе с тем осознание воспроизводимых буквенных комплексов (слов) (1), как сложное действие, которое с одной стороны является речевым (интеллектуальным), а с другой двигательным (2). Графические умения письма относятся к сенсорным умениям ребенка (5), для их формирования необходимо развитие движений пальцев и кисти руки $(10,11)$. Важным условием для формирования навыка письма для дошкольника и младшего школьника является развитие моторного компонента двигательного анализатора, рука должна быть готова для непосредственного выполнения точных и сложных движений орудием для дальнейшей деятельности (2).

У слабовидящих детей из-за недостаточного запаса предметных и пространственных представлений наблюдается отставание в развитии осязания и мелкой моторики, что проявляется в низком уровне овладения ими сенсорными эталонами, несформированности знаний о строении и функциях руки, разрыве между предметнопрактическими действиями и их словесным обозначением (5).

Графические умения и навыки формируются в тесной зависимости от уровня развития зрительного воспри- 
ятия, пространственной ориентировки, зрительно-моторной координации.

Исследователи выделяют особенности восприятия детей с нарушениями зрения: замедленность, фрагментарность, схематизм, неточность, трудности выделения фигуры на фоне и деталей в сложных изображениях (4, 7).

Из-за низкой скорости осуществления перцептивных операций, несформированности, неполноты, нечёткости образов-представлений процесс переработки слабовидящими детьми информации в процессе восприятия замедляется. Это сказывается на формировании графомоторных навыков. Зрительное восприятие сложная система деятельности, включающая сенсорную обработку визуальной информации, её оценку, интерпретацию и категоризацию.

Понятие «зрительно-моторная координация» в педагогической литературе рассматривается, как зрительный контроль за координированным движением руки (3). Зрительно-моторная координация относится к одной из сторон зрительного восприятия, что очень часто страдает в условиях нарушения зрительных функций. Таким образом, нарушения зрения отрицательным образом сказываются на становлении письменной речи таких детей: формирование графомоторных умений и навыков происходит с трудом и растянуто во времени. Для подготовки старших дошкольников к обучению в школе необходимо проведение специальной коррекционной работы по подготовке руки к письму.

Для выявления особенностей графомоторных умений и навыков у дошкольников со зрительной патологией нами был проведен эксперимент. В экспериментальную группу вошло 20 детей в возрасте 6-7 лет. Все дети, которые принимали участие в эксперименте, относятся к категории слабовидящих детей и являются воспитанниками дошкольного отделения ГБОУ СО «Школа-интернат АОП №3 г. Саратова»

На начальном этапе исследования были подобраны материалы и методики для проведения мониторинга, а также проведена первичная диагностика уровня сформированности графомоторных умений и навыков у детей исследуемой группы.

Исследование проводилось в группе детей, с которыми мы непосредственно ведём работу, поэтому установить эмоциональный контакт с дошкольниками было легко, что способствовало получению достоверных результатов эксперимента. Исследование проводилось в кабинете, где дети работают со специалистами и воспитателями каждый день, обстановка была знакома, что тоже способствовало благоприятному эмоциональному фону.

При составлении программы диагностического исследования были учтены следующие требования:

1. задания отвечали требованиям той программы, по которой обучаются дети в данном учреждении и отвечали их возрастной норме;

2. задания охватывали задачи разделов программы по формированию графомоторных умений и навыков;

3. используемые задания были аналогичны тем, что ранее дети выполняли во время обучения, но с другими материалами и пособиями;

4. в задания были включены упражнения на использование умений, знаний, навыков в новых ситуациях и условиях.

Диагностические материалы и методики для определения уровня сформированности графомоторных умений и навыков у детей отвечали требованиям Федерального государственного образовательного стандарта.

Для исследования сформированности графомоторных навыков и умений за основу были взяты методики и программы для детей с нарушениями зрения Плаксиной Л.И., Подколзиной Е.Н. и Никулиной Г.В. Система оценки уровня сформированности исследуемых умений и навыков у детей с нарушениями зрения была разработана с учетом программы детского сада. Для эксперимента мы адаптировали и вычленили те позиции, которые нас интересовали, а именно уровень развития графомоторных навыков и умений у детей с нарушениями зрения.

Диагностические задания были разделены на следующие разделы:

- исследование уровня развития тонких движений пальцев рук;

- исследование развития ориентировки в микропространстве;

- исследование уровня развития зрительно-моторной координации.

В результате исследования было выявлено, что только 10\% испытуемых достигли высокого уровня развития графомоторных умений и навыков, 20\% детей показали результаты, которые мы отнесли к среднему уровню, и у 70\% исследуемые навыки и умения не были сформированы, находились на низком уровне. Констатирующий эксперимент показал, что для слабовидящих старших дошкольников характерны следующие недостатки сформированности графомоторных умений и навыков:

- неустойчивость графических форм, замедленность действий при письме и штриховке, колебание наклона, различная ширина и высота элемен- 
тов, что объясняется нескоординированностью моторики частей пишущей руки - пальцев, кисти, плеча, предплечья;

- нарушения ориентировки в микропространстве: несформированность понятий «лево-право», «верх-низ», «верхний правый угол - нижний правый угол», «слева направо», «сверху вниз» и т.д., нарушения строки, границ рабочего поля;

- затруднения в изображении прямой линии, простейших фигур, букв, цифр.

Нами была разработана коррекционная программа по формированию графомоторных навыков у старших дошкольников с нарушениями зрения. Работа проводилась во время занятий кружка «Весёлый карандаш», элементы упражнений и заданий включались также в коррекционную и игровую работу, свободную деятельность детей. Обучающий эксперимент длился 10 недель, занятия проводились три раза в неделю во вторую половину дня на коллективных и подгрупповых (5-6 человек) занятиях по 25 минут. Осуществлялся индивидуальный подход, построенный с учётом качества восприятия, связанный с развитием технических умений и навыков, эмоциональной отзывчивости каждого ребёнка на предложенное задание.

Программа коррекционной работы была направлена на совершенствование навыков тонкой моторики, ориентировки в микропространстве; на развитие процессов зрительного различения, локализации, дифференцировки, опознания; формирование и развитие таких зрительных умений, как умение видеть целое, часть в целом, последовательный анализ зрительного образца, на развитие зрительно-моторной координации.

На занятиях мы использовали ряд различных упражнений, дидактических игр и пособий: трафареты, пальчиковые гимнастики, сухой бассейн с мелкими игрушками, сортировка мелких предметов и круп, застегивание пуговиц, шнуровка, игры с мозаикой, развивающие игры и пособия В.В. Воскобовича и т.д. Упражнения были включены в разнообразную творческую деятельность: рисо- вание, штриховку, раскрашивание, игру на музыкальных инструментах, спортивные игры, игровую деятельность. Детям были интересны знакомые задания, которые надо было выполнить на ощупь (без контроля зрения): собрать пирамидку, бусы, сложить стаканчики-вкладыши, найти в «Волшебном мешочке» нужную геометрическую фигуру. Для выработки серийной организации движений, автоматизации двигательных навыков письма мы использовали рисование орнаментов.

Контрольный эксперимент показал положительную динамику в формировании графомоторных навыков у старших дошкольников с нарушениями зрения, подтвердив эффективность разработанной нами коррекционной программы. 80 \% детей достигли высокого уровня развития графомоторных умений и навыков, 20 \% испытуемых показали средний уровень. Деятельность по разработанной программе способствовала развитию мелкой моторик детей, навыков ориентировки в микропространстве, зрительно-моторной координации, то есть тех значимых функций, которые необходимы для успешного обучения в школе. Дети учились планировать свою работу и доводить её до конца. В итоге по окончании эксперимента мы обнаружили, что уровень графомоторных умений и навыков испытуемых повысился.

Таким образом, несовершенство процесса переработки сенсорной информации, неполноценность пространственного анализа и аналитико-синтетической деятельности детей исследуемой группы затрудняют соотнесение выделенной формы со зрительным образом. Недостаточность информации зрительного восприятия, несформированность мелкой моторики, наблюдаемая у детей с нарушениями зрения, трудности их ориентировки в пространстве являются одной из причин испытываемых ими затруднений при формировании графомоторных навыков. Всё это говорят о необходимости проведения специальной коррекционной работы по преодолению выявленных недостатков для обеспечения успешности обучения в школе детей с нарушениями зрения.

\section{ЛИТЕРАТУРА}

1. Агаркова Н Г. Формирование графического навыка письма у младших школьников [Текст] / Н.Г. Агаркова. - М.: Просвещение, 1987. - 129 с.

2. Аксенова А.К. Методы обучения русскому языку в коррекционной школе. - М.: Владос, 2014. - 106 с.

3. Корнев А.Н. Нарушения письма и чтения у детей (диагностика, коррекция, предупреждение). - М.: Издательский дом «М и М», $2204-218$ с.

4. Литвак А.Г. Психология слепых и слабовидящих: учеб. пособие / А.Г. Литвак ; Рос. гос. пед. ун-т им. А.И. Герцена. -- СПб. : Изд-во РГПУ, 1998. - 271 с.

5. Лурия А.Р. Письмо и речь: нейролингвистические исследования [Текст] / А.Р. Лурия. - М.: Академия, 2002. - 304 с.

6. Мясникова Л.В. Развитие осязания и мелкой моторики у младших школьников в процессе коррекционного обучения: автореф. ....дис. канд. пед. наук: 13.00.03 / Л.В. Мясникова; ГНУ «Институт коррекционной педагогики Российской Академии образования» - Москва, 2005. -25 с.

7. Плаксина Л.И. Развитие зрительного восприятия у детей с нарушением зрения в процессе предметного рисования. -- М.: Владос, 2021. - 87 с.

8. Российская Е.Н. Методика формирования самостоятельной письменной речи у детей. - М.: Айрис - пресс, 2004. -240 с. 
9. Садовникова И.Н. Нарушения письменной речи и их преодоление у младших школьников. - М.: ВЛАДОС, 1997-255 С.

10. Сальникова Т.П. Методика обучения грамоте. Учеб. - метод. пос. для студ. и препод. пед. заведений / Т.П. Сальникова. - М. : Изд. Ин-т практ. псих.; Воронеж : Изд. НПО МОДЭК, 2010. - 190 с.

11. Скиотис Е.И. Особенности развития связной письменной речи младших школьников с задержкой психического развития / Е.И. Скиотис // Дефектология. - 2006. - №6. - C. 24-27.

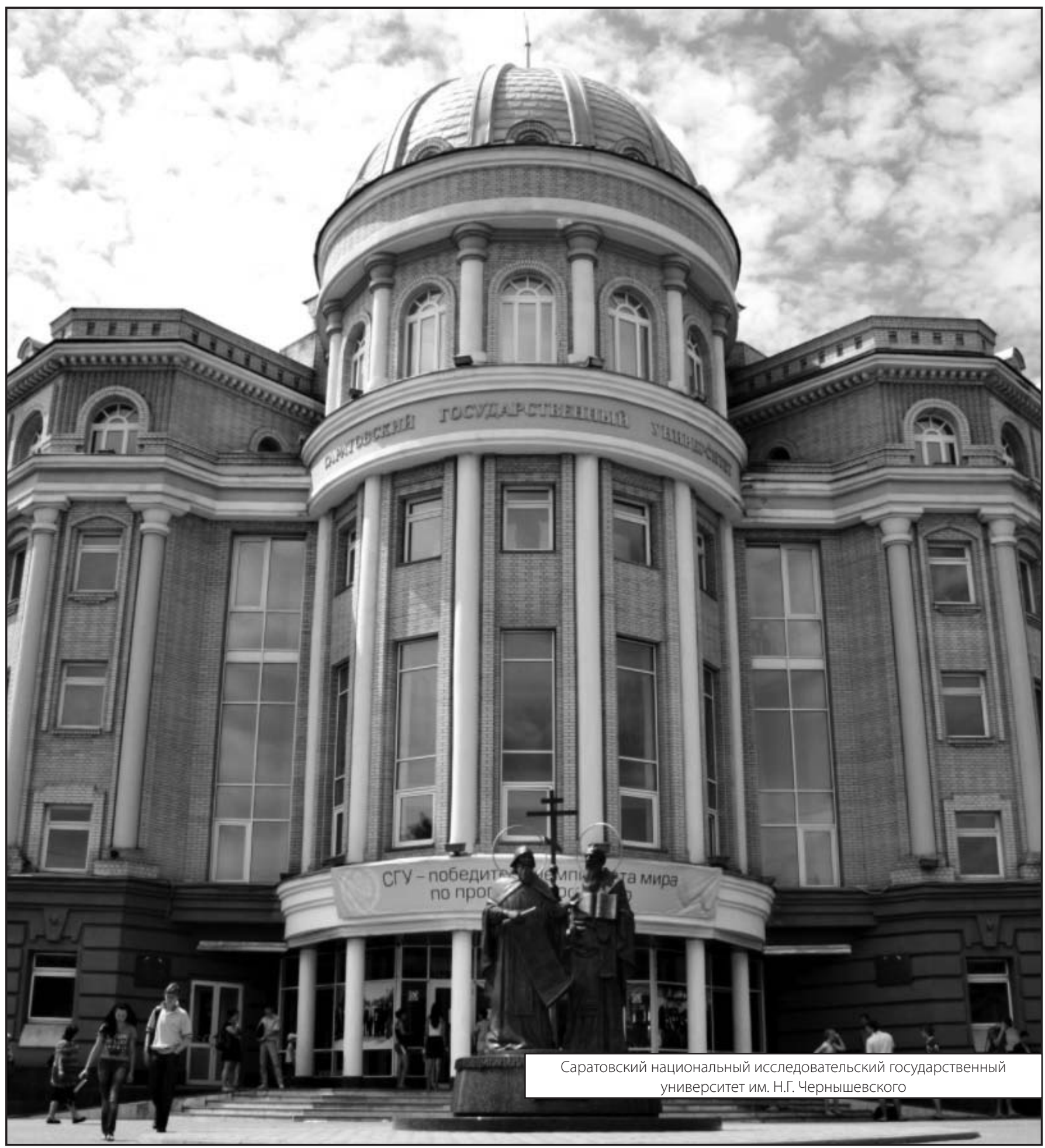

